\title{
ECU calibration for gaseous dual fuel supply system in compression ignition engines
}

The dual fuel (DF) combustion mode is proven solution that allows to improve or get at the same level engine performance and reduce toxic compounds in exhaust gases which is confirmed by researchers and end-users. DF combustion mode uses two fuels gaseous fuel as a primary energy source and a pilot quantity of diesel fuel as ignition source. However, in order, to fully take advantage of the potential of the dual fuel mode, DF system must be proper calibrated. Despite the existence of commercial control systems for dual fuel engines on the market, the literature on the important parameters for the engine's operation introduced during calibration is scarce. This article briefly describes a concept of working algorithm and calibration strategy of a dual fuel electronic control unit (ECU) The purpose of calibration is to achieve the greatest possible use of an alternative gaseous fuel without causing accelerated engine wear.

Key words: compression ignition engine, ECU calibration, dual fuel mode, alternative fuels, emission reduction

\section{Introduction}

Despite the fact that the crude oil reserves will drain away in the near future (oil will sufficiently meet the worldwide demand for another 39 years [3, 7]), fuel demand is increasing in many sectors, especially in transportation sector (Fig. 1). Depletion of the non-renewable fossil resources leads to energy and political crisis.

Moreover, transport sector is a major contributor to the harmful gas emissions in the world, with a share of about 23.5-28\% [1, 5, 19]. That brings us to environmental concerns caused by the rapid increase of harmful exhaust emissions due to the burning of fossil fuels. Depletion of crude oil and environmental considerations are driving the research towards the alternative combustion modes, exhaust after-treatment systems and nonconventional fuel sources.

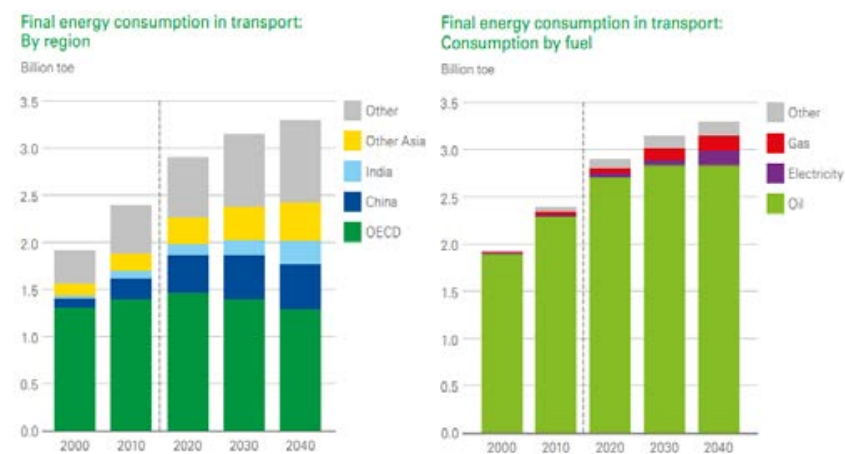

Fig. 1. Energy consumption in transport [3] (* other includes biofuels, coa and hydrogen)

Diesel engines have been widely used in heavy-duty vehicles, construction equipment, buses, and diesel generators due to its unmatched efficiency, durability and flexibility compared to a spark ignition engines. However, diesel engines are one of the main sources of the nitrogen oxides $\left(\mathrm{NO}_{\mathrm{x}}\right)$ and particulate emissions $(\mathrm{PM})$. In order to lower $\mathrm{NO}_{\mathrm{x}}$ and $\mathrm{PM}$ emissions an after treatment systems have been widely used in diesel engines. However, catalyst materials are highly expensive and current technology cannot afford stringent emission regulations.
Thus, turning us to alternative energy sources such as: biogas, liquefied petroleum gas (LPG), compressed natural gas (CNG), liquefied natural gas (LNG) etc. The use of alternative gaseous fuels is a promising approach that allows to lower the dependence on conventional fuels and to reduce the harmful compounds in exhaust gases, which has been confirmed by numerous investigations [3, 4, 7, 10-13, $17,18]$ and many others. However, the additional gaseous fuel burned with diesel fuel does not always have a positive effect on the content of toxic exhaust components. This applies, for example, to hydrogen, which was described in the doctoral dissertation [6].

Another not at all les important factor that determining the alternative fuels perspectives is a fuel price competition (Table 1). Each fuel has different calorific value so it is important to compare fuels with their energy content as kilowatt hour. In this way, the differences between fuels in terms of energy content would be directly visible without the "detour" of a reference fuel [9].

Table 1. Comparison of fuel prices [9]

\begin{tabular}{|l|c|c|c|c|}
\hline \multirow{2}{*}{ Type of fuel } & \multicolumn{2}{|c|}{ Energy content } & Price & Price* $^{*}$ \\
\cline { 2 - 5 } & {$[\mathrm{MJ} / \mathrm{l}]$} & {$[\mathrm{kWh} / \mathrm{l}]$} & {$[€ / \mathrm{l}]$} & {$[€ / 10 \mathrm{kWh}]$} \\
\hline Petrol & 32 & 8.88 & 1.536 & 1.730 \\
\hline Diesel & 36 & 10 & 1.398 & 1.398 \\
\hline Natural gas & 44.4 & 12.3 & 1.103 & 0.897 \\
\hline Biogaz (biomethane) & 44.4 & 12.3 & 1.103 & 0.897 \\
\hline LPG & 24 & 6.6 & 0.693 & 1.050 \\
\hline$* 10 \mathrm{kWh}$ is equivalent to the energy content in one liter of diesel fuel \\
\hline
\end{tabular}

All this factors that mentioned above promote an important increment in the use of gaseous fuels as alternative fuels in the transportation sector in the recent years (Fig. 1).

However, engine operation on such alternative fuels may be sub-optimal with regard to both combustion process, fuel economy and emissions performance, as the engine has been designed and calibrated for operation on conventional fuel. Thus, the use of alternative fuels requires the calibration of the engine operating conditions including injection strategy and control parameters of the engine dual fuel electronic control unit, in relation to the physicochemical properties of alternative fuels. 


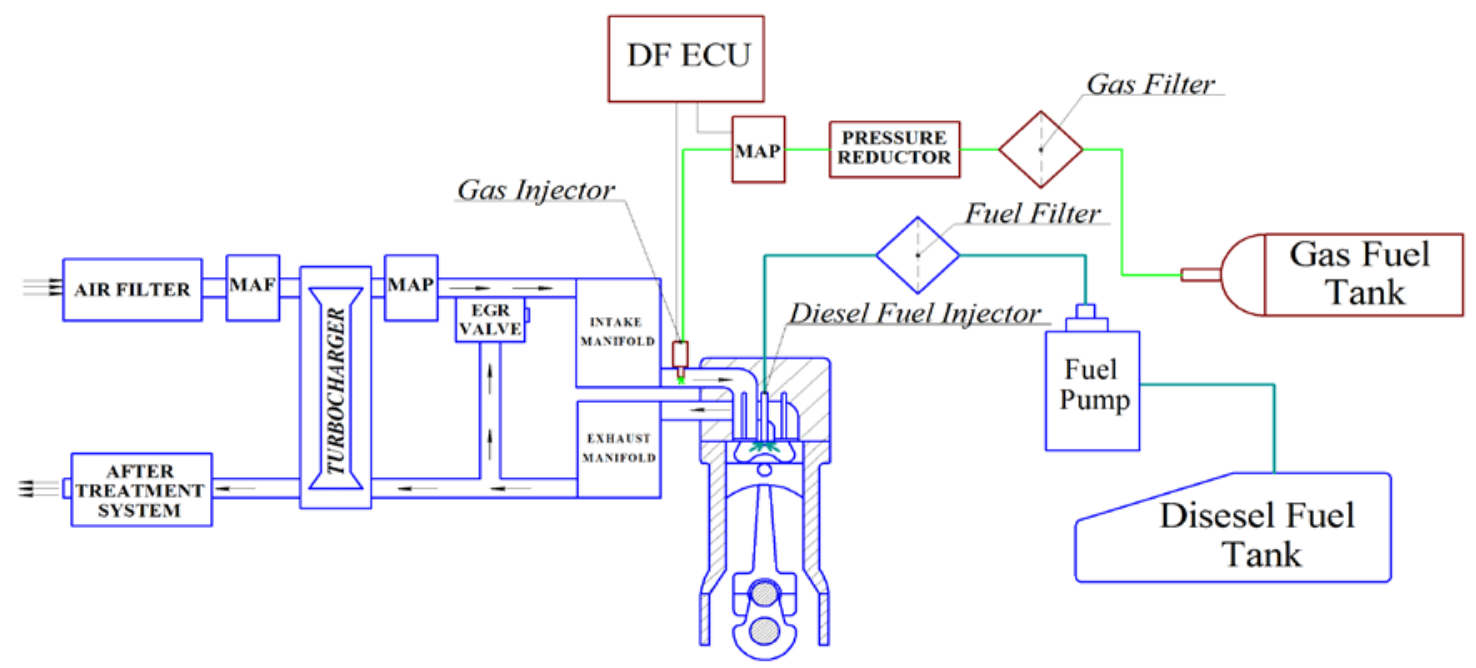

Fig. 2. Simple* overall scheme of Dual fuel mode in AJM 1.9 TDI (*Does not contain all electrical connections)

The dual fuel engine has some pitfalls such as the poor utilization of the LPG fuel at low and intermediate loads which results in poor engine performance, high $\mathrm{HC}$, CO emissions and misfiring at higher gas inducted levels. Poor part load performance results from incomplete combustion of LPG. Due to this poor thermal efficiency high level of unburnt hydrocarbons in the exhaust is found. The performance of a dual fuel engine at idling and low loads can be improved by optimizing some engine operating and design parameters, such as engine speed, load, pilot fuel quantity, injection timing, intake manifold condition and intake gaseous fuel compositions [2].

In order to perform DF ECU calibration used special software solutions dedicated by ECU manufacturers [14, 16] and many others. This software, vary visually and may use various principle to reduce the amount of fed diesel. On the one hand, software that uses „diesel oil reduction map” and emulate common rail pressure signal [16], another software uses „emulator map” to emulate APP, MAP and MAF signals individually or simultaneously [14]. As, a reference software for DF ECU calibration in this work second type software was selected, due to more calibration freedom.

The present work is a part of an extensive experimental investigation devoted to the calibration DF ECU control parameters in order to finding the best compromise between reduction of fed diesel, engine performance and emission.

The purpose of this paper is to briefly describe a concept of working algorithm and "traditional" calibration strategy of a "gas diesel” ECU and to share useful information with researchers, engineers and anyone who interested in calibration of DF ECU control parameters in order to use alternative fuels in more efficient way.

\section{Diesel engine modifications}

There are a variety of technologies to meter gaseous fuels for internal combustion engines. These technologies vary in cost and complexity. For example, due to a high octane number of LPG and CNG they can be used in spark ignition engines in lover cost without major modifications. In contrast, low cetane number and high self-ignition tem- perature (Table 2) (bad self-ignition abilities during the compression) of gaseous fuels (LPG, LNG, CNG) makes them difficult to be used in large proportions in compression ignition engines.

Table 2. Fuel properties

\begin{tabular}{|l|c|c|c|c|}
\hline $\begin{array}{l}\text { Parameter/Fuel } \\
\text { type }\end{array}$ & Diesel Fuel & Butane & Propane & Methane \\
\hline $\begin{array}{l}\text { Self-ignition } \\
\left.\text { temperature [ }{ }^{\circ} \mathrm{C}\right]\end{array}$ & 254 & 365 & 470 & 470 \\
\hline Cetane number & $40-55$ & 10 & 5 & 0 \\
\hline Octane number & - & 102 & 102 & 120 \\
\hline
\end{tabular}

However, there are two main application modes of gaseous fuels in compression-ignition engines:

1. Single fuel mode. This solution technically is very complex and requires intervention in the engine block and installation of additional spark plug as ignition source. Moreover, conventional electronic control unit for proper engine work must be calibrated.

2. Dual fuel mode (Fig. 2). In this operation mode gaseous fuels in a liquid or gaseous form inducted into the intake air of the inlet manifold to form homogeneous mixtures and then ignited by the directly injected pilot quantity of diesel fuel in the cylinder at the end of the compression stroke. This mode is inexpensive and requires only minor modifications by adding typical components ("auto gas" conversion kit), e.g. fuel tank with auxiliaries, gas filter, fuel lines, LPG/CNG injectors, reducers, additional sensors, signal emulators and dual fuel electronic control unit.

Due to simplicity and lower engine failure possibility, the second solution is widely used.

\section{Dual fuel ECU working concept}

There are many conversion kits for diesel engines available commercially. But, working algorithm is the same.

The DF ECU in order to operate in dual fuel mode requires signals from the crank position sensor (RPM), accelerator pedal position sensor (APP), manifold absolute pressure (MAP) sensor and mass air flow (MAF) sensor and additional sensors from dual fuel conversion kit (Fig. 3). During the dual fuel operation, the gas injector will be 
controlled by the DF ECU while the diesel injector shall be controlled by the conventional ECU. In this mode, a portion of the fed diesel needs to be reduced and then replaced with gaseous fuel. In order to do so, DF ECU reads the lookup tables called "maps" (Fig. 4, 5) and produces continuous emulated/modified signal of the sensors (APP, MAF, MAP) and fed it into diesel ECU and then DF ECU set the injection duration for gas injectors. Depending on the received signal, the conventional ECU changes diesel fuel quantity. The set of parameters for the lookup tables obtained from experimental studies via calibration algorithm (discussed later in the article).

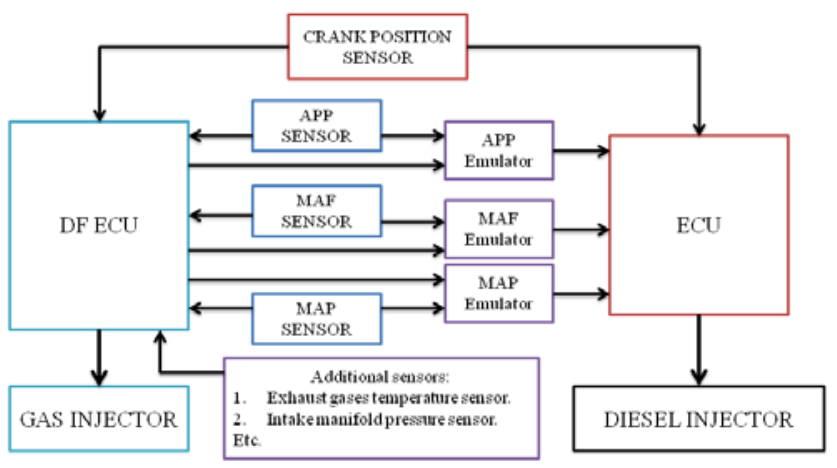

Fig. 3. Dual fuel mode control setup

Fig. 4 shows “emulation map”. Based on the set values contained in the map the amount of fed diesel could be changed (reduced or increased). The upper bar in the map represents the signal's voltage. This map allows to set individual emulation strength (in percentage) for active analog emulator (E1, E2, E3) and/or digital emulator (De1, De2) according to emulated signal's value [14].

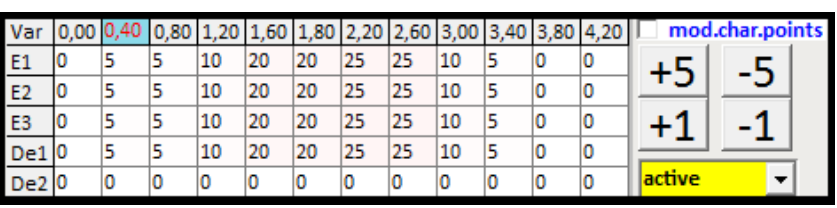

Fig. 4. Emulator lookup table [14]

Figure 5 demonstrated different type of map. The set values in the "gas map" has an integer range between 0 and 254 , where such values produce the gas dosage from $0 \%$ to $100 \%$ respectively. Gas map contains set values that correspond revolutions per minute ( $\mathrm{X}$ axis) and pressure in the intake manifold (Y axis). Depending on the engine actual rpm and pressure inside intake manifold DF ECU choose correspond value in the map and increase the amount of gaseous fuel. However, set values in the "gas map", does not represent exact fuel quantity and does not give absolute injection duration of the gas fuel. Those values are used as a reference, taking into consideration the number of gas injector installed and their static flow rate in order to gas fuel injection quantity calculation.

The percentage of the premixed gas can be quantified as substitution ratio on an energy basis according to the following equation [7]:

$$
\mathrm{SR}=\frac{\dot{\mathrm{m}}_{\mathrm{G}} \times \mathrm{LHV}_{\mathrm{G}}}{\dot{\mathrm{m}}_{\mathrm{D}} \times \mathrm{LHV}_{\mathrm{D}}+\dot{\mathrm{m}}_{\mathrm{G}} \times \mathrm{LHV}_{\mathrm{G}}} \times 100 \%
$$

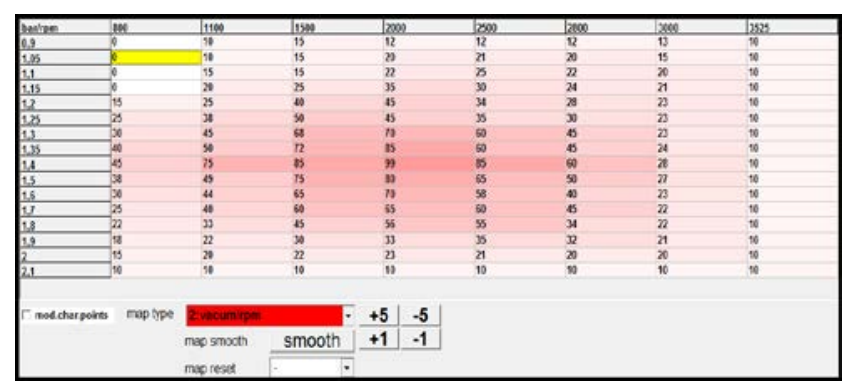

Fig. 5. Gas fuel lookup table [14]

Reducing the fed diesel quantity and increasing gas substitutions ratio means changing the air-fuel ratio $(\lambda)$. In order to ensure similar engine performance for both single fuel (diesel only) mode and dual fuel mode the air-fuel ratio must be at the same level.

Another, not at all less important problem that can arise when two fuels are fed simultaneously, is a risk of the engine thermal and/or mechanical overloading. In order to protect the engine against failure, DF ECU measured the exhaust gas temperature and rpm. The maximum values of the exhaust gas temperature and rpm are entered as a boundary gas cut-off conditions in the software during the calibration procedure (Fig. 6).

In addition, knock effects can occurs in the engine during the combustion. To identify this effect DF ECU requires additional signal from knock sensor. One way to limited this phenomenon could be reducing of the gas substitution ratio. From the other hand this phenomenon can be limited by increasing injection time delay of pilot diesel.

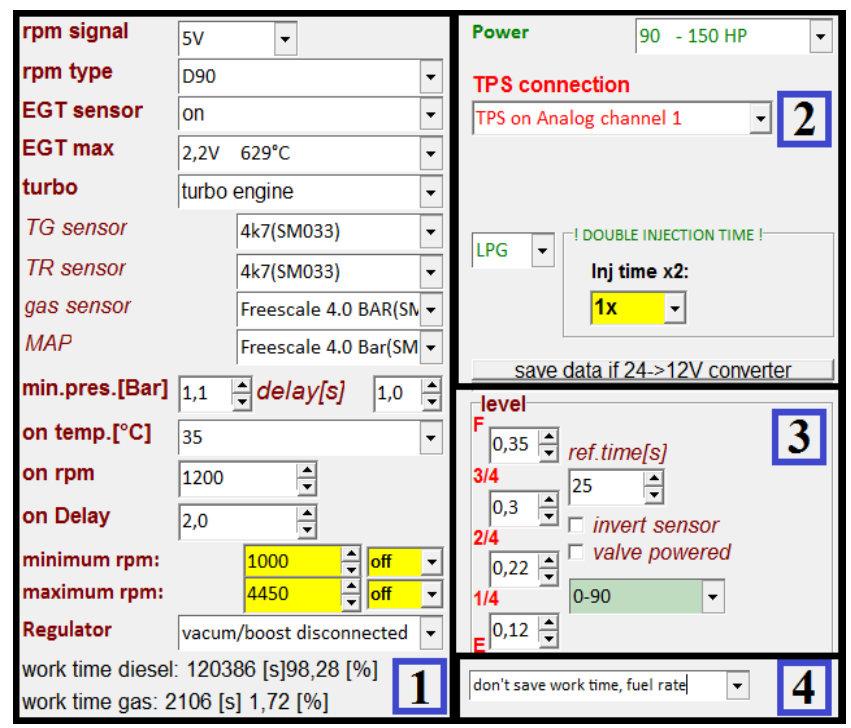

Fig. 6. DF ECU basic configuration screen [14]: 1 - main parameters, 2 additional parameters, 3 - level sensor settings, 4 - save function

\section{Dual fuel ECU calibration}

ECU calibration is the process of determining the optimal balance between several parameters correlated with each other and the engine operating conditions. This process helps to identify the optimal balance of engine performance, emissions, and fuel economy. The common goal of 
this process is to achieve maximum substitution rate of fed diesel, while still meeting all the requirements (Table 3).

As mentioned by authors [17] providing LPG “auto gas” and increasing its injection time (at constant emulation level) results in a non-linear increase in temperature, nonlinear decrease in the air-fuel equivalence ratio, the initial growth of the vehicle's power, and after a certain point its decline and uneven operation of the engine. The lack of simple relations in case of a simultaneous changes of the control parameters (gas injection duration, APP, MAF and MAP emulation). As a result, DF ECU calibration process is becoming more difficult to optimize, and it cannot be put in a simple framework of mathematical relations or linear patterns.

The calibration procedure itself does not seem complicated (evident in Fig. 7). However, it is a laborious trial and error process in finding the optimal balance between parameters in the full range of the engine working cycle. The "traditional", testing-intensive method in comparison with modern numerical model-based calibration methods (zero dimensional models, CFD models) is sub-optimal with regard to time consumption and requires many engine data driving cycles. However, "traditional" calibration method can be quite effective, when it is impossible to gather all required data to prepare proper zero dimensional or CFD model.

Table 3. Requirements for dual fuel system $[8,11]$

\begin{tabular}{|l|l|}
\hline No. & \multicolumn{1}{|c|}{ Requirement } \\
\hline 1 & $\begin{array}{l}\text { Obtaining the same air-fuel equivalence ratio }(\lambda) \text { for an engine } \\
\text { running in single- or dual- fuel mode. }\end{array}$ \\
\hline 2 & No noticeable increase in exhaust gases temperature. \\
\hline 3 & $\begin{array}{l}\text { No noticeable increase/decrease in engine output power after } \\
\text { switching into dual fuel mode. }\end{array}$ \\
\hline 4 & Steady work of engine in dual fuel mode (no jerking). \\
\hline 5 & $\begin{array}{l}\text { Lowering amount of toxic emissions in the exhaust gases, } \\
\text { especially } \mathrm{NO}_{\mathrm{x}} \text { and PM. }\end{array}$ \\
\hline
\end{tabular}

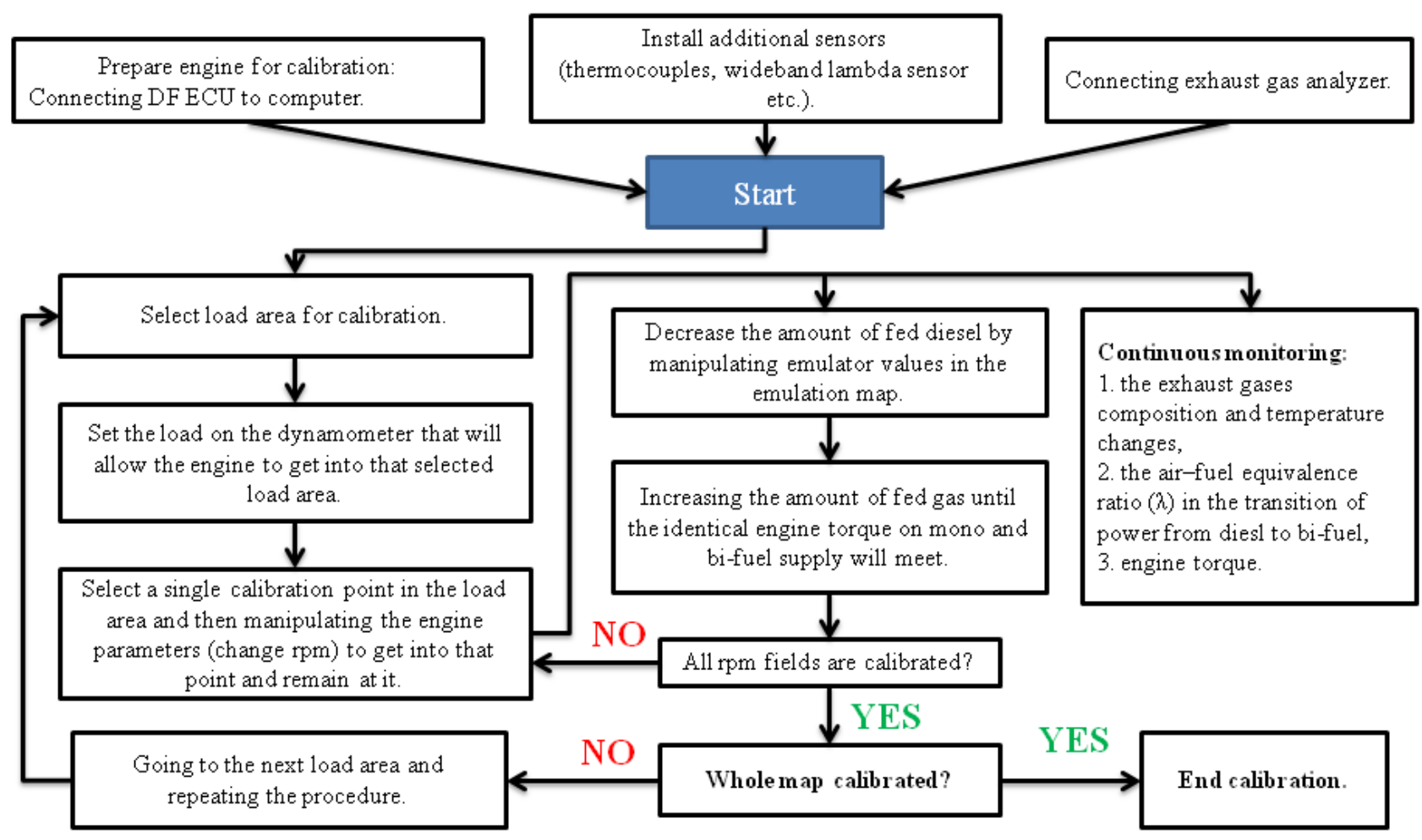

Fig. 7. DF ECU calibration algorithm

\section{Conclusions}

The "Dual fuel combustion concept" is a relatively simple strategy that allows to lowering the dependence on petroleum based liquid fuels and reduce the harmful compounds in exhaust gases. The modification work for the conversion of any diesel engine into the dual fuel system is inexpensive and requires minimum installation of additional components.

In terms of calibration, the proper DF ECU calibration is a laborious process that requires knowledge and experience. It is important to perform proper calibration because its quality has a very large impact on the combustion process, fuel economy and emission performance that is confirmed by numerous investigations. The purpose of calibration is to achieve the greatest possible use of an alternative gaseous fuel. This goal is best achieved by using a feedback loop as a function of exhaust gas temperature or control based on the measurement of the pressure in the intake manifold. Exceeding the permissible exhaust gas temperature should be assumed as a criterion for the assessment of possible engine damage with too large substitution of diesel oil by gaseous fuel. 


\section{Nomenclature}

APP accelerator pedal position

CNG compressed natural gas

DF dual fuel

ECU electronic control unit

$\mathrm{LHV}_{\mathrm{G}}, \mathrm{LHV}_{\mathrm{D}}$ the lower calorific values of gas and diesel fuels
LNG liquefied natural gas

LPG liquefied petroleum gas

$m_{G}, m_{D}$ the mass flow rates of gas and diesel fuels

MAF mass air flow

MAP manifold absolute pressure

SR substitution ratio

\section{Bibliography}

[1] Agency, E.E. Greenhouse gas emissions from transport in Europe. https://www.eea.europa.eu. 2019.

[2] ASHOK, B., DENIS ASHOK, S. et al. LPG diesel dual fuel engine - a critical review. Alexandria Engineering Journal. 2015, 54(2), 105-126.

https://doi.org/10.1016/j.aej.2015.03.002

[3] BP, E. BP Energy Outlook 2019 edition. The Energy Outlook explores the forces shaping the global energy transition out to 2040 and the key uncertainties surrounding that. 2019.

[4] BRZEŻAŃSKI, M., GOLEC, K. Nowoczesne systemy zasilania silników spalinowych paliwami gazowymi. Zeszyty Naukowe Politechniki Częstochowskiej. Seria Mechanika, Silniki Gazowe. 2003, 25.

[5] CHEN, X., WANG, Z., PAN, S. et al. Improvement of engine performance and emissions by biomass oil filter in diesel engine. Fuel. 2019, 235, 603-609.

https://doi.org/10.1016/j.fuel.2018.08.038

[6] DASZKIEWICZ, P. Badania możliwości poprawy wskaźników ekologicznych silników o zapłonie samoczynnym zasilanych paliwami konwencjonalnymi z domieszką wodoru. Doctoral Disertation, Poznań 2014.

[7] GENG, P., CAO, E., TAN, Q. et al. Effects of alternative fuels on the combustion characteristics and emission products from diesel engines: a review. Renewable and Sustainable Energy Reviews. 2017, 71, 523-534.

https://doi.org/10.1016/j.rser.2016.12.080

[8] JARZYŃSKI, W., KNEBA, Z. Research on the influence and the methodology of the calibration process for dieselLPG dual fuel supply systems. Combustion Engines. 2015, 162(3), 649-657.

[9] KOLB, O., SIEGEMUND, S. Final report: study on the implementation of Article 7(3) of the "Directive on the deployment of alternative fuels infrastructure" - fuel price comparison. German Energy Agency 2017.

Denys Stepanenko, MEng. - Faculty of Mechanical Engineering, Gdansk University of Technology. e-mail:denys.stepanenko@pg.edu.pl
[10] MERKISZ, J., PIELECHA, I. Alternatywne paliwa i układy napędowe pojazdów. Wydawnictwo Politechniki Poznańskiej, Poznań 2004.

[11] NAPOLITANO, P., FRAIOLI, V., GUIDO, C. et al. Assessment of optimized calibrations in minimizing GHG emissions from a dual fuel NG/diesel automotive engine. Fuel. 2019, 258, 115997. https://doi.org/10.1016/j.fuel.2019.115997

[12] PARK, S.H., LEE, C.S. Applicability of dimethyl ether (DME) in a compression ignition engine as an alternative fuel. Energy Conversion and Management. 2014, 86, 848863. https://doi.org/10.1016/j.enconman.2014.06.051

[13] QI, D.H., BIAN, Y.Z., MA, Z.Y. et al. Combustion and exhaust emission characteristics of a compression ignition engine using liquefied petroleum gas-diesel blended fuel. Energy Conversion and Management. 2007, 48(2), 500-509. https://doi.org/10.1016/j.enconman.2006.06.013

[14] SCALMAX. Scalmax Diesel Software Manual. 2018.

[15] SEMELSBERGER, T.A., BORUP, R.L., GREENE, H.L. Dimethyl ether (DME) as an alternative fuel. Journal of Power Sources. 2006, 156(2), 497-511. https://doi.org/10.1016/j.jpowsour.2005.05.0822016

[16] STAG. CLB-2000/LB-2000 Installation and Configuration Manual. 6377. 2000.

[17] STELMASIAK, Z., LARISCH, J., PIELECHA, J. et al. Particulate matter emission from dual fuel diesel engine fuelled with natural gas. Polish Maritime Research. 2017, 24(2). https://doi.org/10.1515/pomr-2017-0055

[18] STELMASIAK, Z., LARISCH, J., PIETRAS, D. Selected problems of adaptation car diesel engine for dual fuel supplying. Combustion Engines. 2015, 162(3), 1021-1029.

[19] US Environmental Protection Agency. Inventory of US. Greenhouse Gas Emissions and Sinks: 564. 2015. https://doi.org/EPA 430-R-13-001

Zbigniew Kneba, DSc., DEng. - Faculty of Mechanical Engineering, Gdansk University of Technology. e-mail: zkneba@pg.edu.pl
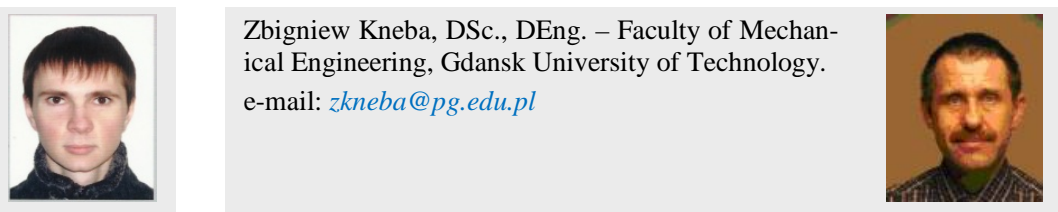